\title{
Water-use efficiency in response to simulated increasing precipitation in a temperate desert ecosystem of Xinjiang, China
}

\author{
HUANG Gang $^{1 *}$, LI Yan ${ }^{1}$, MU Xiaohan ${ }^{1}$, ZHAO Hongmei ${ }^{2}$, CAO Yanfeng ${ }^{3}$ \\ ${ }^{1}$ State Key Lab of Desert and Oasis Ecology, Xinjiang Institute of Ecology and Geography, Chinese Academy of Sciences, \\ Urumqi 830011, China; \\ ${ }^{2}$ Xinjiang Key Laboratory of Soil and Plant Ecological Processes, College of Grassland and Environmental Sciences, Xinjiang \\ Agricultural University, Urumqi 830052, China; \\ ${ }^{3}$ Geology Science Department, Shannxi Normal University, Xi’an 710062, China
}

\begin{abstract}
Water-use efficiency (WUE) is a key plant functional trait that plays a central role in the global cycles of water and carbon. Although increasing precipitation may cause vegetation changes, few studies have explored the linkage between alteration in vegetation and WUE. Here, we analyzed the responses of leaf WUE, ecosystem carbon and water exchanges, ecosystem WUE, and plant community composition changes under normal conditions and also under extra $15 \%$ or $30 \%$ increases in annual precipitation in a temperate desert ecosystem of Xinjiang, China. We found that leaf WUE and ecosystem WUE showed inconsistent responses to increasing precipitation. Leaf WUE consistently decreased as precipitation increased. By contrast, the responses of the ecosystem WUE to increasing precipitation are different in different precipitation regimes: increasing by $33.9 \%$ in the wet year (i.e., the normal precipitation years) and decreasing by $4.1 \%$ in the dry year when the precipitation was about $30 \%$ less than that in the wet year. We systematically assessed the herbaceous community dynamics, community composition, and vegetation coverage to explain the responses of ecosystem WUE, and found that the between-year discrepancy in ecosystem WUE was consistent with the extent to which plant biomass was stimulated by the increase in precipitation. Although there was no change in the relative significance of ephemerals in the plant community, its greater overall plant biomass drove an increased ecosystem WUE under the conditions of increasing precipitation in 2011. However, the slight increase in plant biomass exerted no significant effect on ecosystem WUE in 2012. Our findings suggest that an alteration in the dominant species in this plant community can induce a shift in the carbon- and water-based economics of desert ecosystems.
\end{abstract}

Keywords: desert ecosystem; ecosystem water-use efficiency; gross carbon exchange; increasing precipitation; leaf water-use efficiency; net carbon exchange; Gurbantunggut Desert

Citation: HUANG Gang, LI Yan, MU Xiaohan, ZHAO Hongmei, CAO Yanfeng. 2017. Water-use efficiency in response to simulated increasing precipitation in a temperate desert ecosystem of Xinjiang, China. Journal of Arid Land, 9(6): 823-836. https://doi.org/10.1007/s40333-017-0021-7

\section{Introduction}

Precipitation is the determining factor for plant growth, community composition, and ecosystem functioning in deserts (Webb et al., 1983; Austin et al., 2004; Lal, 2004). Changes in the precipitation amount, frequency, interval, and seasonality can induce substantial alterations in the carbon cycling and water use strategies of plants (Robertson et al., 2010). However, it remains

*Corresponding author: HUANG Gang (E-mail: hg@ms.xjb.ac.cn)

Received 2017-02-20; revised 2017-9-5; accepted 2017-09-11

(C) Xinjiang Institute of Ecology and Geography, Chinese Academy of Sciences, Science Press and Springer-Verlag GmbH Germany 2017 
unclear how variation in precipitation affects the carbon exchange and water-use efficiency (WUE) at the ecosystem level (Huxman et al., 2004; Potts et al., 2006; Thomey et al., 2011).

WUE is a comprehensive index of carbon and water fluxes and is recognized as an important functional trait of plant individuals and communities (Le Houerou, 1984; Linderson et al., 2012). WUE is closely related to plant photosynthesis and evapotranspiration, and thus represents a plant adaptive strategy at both the leaf and ecosystem scales (Eamus et al., 2013). Changes in WUE at different scales may reflect the responses of plants to different ecological processes. Leaf WUE is mainly controlled by plant stomata (Toft et al., 1989; Golluscio and Oesterheld, 2007), and leaf WUE responses to increasing precipitation depend on the relative changes in photosynthesis and transpiration (Cohen, 1970; Golluscio and Oesterheld, 2007). Ecosystem WUE integrates the comprehensive responses of vegetation composition and ecosystem evaporation for a given community (Law et al., 2002). Although ecosystem productivity is positively correlated with precipitation across a sufficiently large spatial scale, ecosystem WUE may either increase or decrease with increasing precipitation (Varnamkhasti et al., 1995; Veron et al., 2002; Scanlon and Albertson, 2004; Hastings et al., 2005), and the consensus on how ecosystem WUE responds to increasing precipitation is still lacking (Le Houerou, 1984; Bell et al., 2012; Liu et al., 2012). The lack of consensus arises probably because the photosynthetic assimilation of dominant plant species often determines the magnitude of net primary production (NPP) responses to increasing precipitation (Golluscio and Oesterheld, 2007). Moreover, vegetation coverage further influences the proportion of plant transpiration that contributes to ecosystem evaporation (Huxman et al., 2004). Since water and carbon fluxes are coupled at the ecosystem level and both depend on plant community composition, studies on the variation of WUE at different scales (leaf vs. community) can reveal the internal responses of ecological process to background climate changes (Linderson et al., 2012).

The Gurbantunggut Desert in northwestern China represents an important part of the temperate desert biome in Central Asia, one that is predicted to experience increasing precipitation from 2001 to 2030 (Liu et al., 2010). The objectives of this study were threefold: (1) to test the responses of WUE, at both leaf and ecosystem levels, to increasing precipitation and to analyze the relationships between WUE at the two scales; (2) to explore how community composition changes under increasing precipitation might influence ecosystem WUE; and (3) to test whether the WUE of the herbaceous community under shrub canopies and in interplant habitats exhibits a consistent response to increasing precipitation. Specifically, we tested two proposed hypotheses: first, ephemerals and summer-annuals are the two major plant functional groups in the Gurbantunggut Desert, which undergo a community shift in their dominance from ephemerals in April-early June to summer-annuals in early June-August. Since the relative density of these plants and their phenology also change with increasing precipitation, we hypothesized that WUE at both the leaf and ecosystem levels would increase in response to increasing precipitation for sustaining ephemeral growth. The WUE at community level, however, would decrease the limited stimulation of summer-annual growth due to low productivity and high soil respiration and evaporation. Second, our study site exhibits a typical mosaic landscape, with "fertilized islands" occurring under shrub canopies. The canopies are featured by cyanobacterial-lichen crusts that in turn cover the soil in the interplant matrix ( $\mathrm{Su}$ et al., 2007, 2013; Li, 2012). Since plant biomass in the interplant space was higher than that found beneath the shrubs in a normal precipitation year, but similar in a dry year (Huang et al., 2015), we hypothesized that ecosystem WUE for the interplant area would also exceed that of the beneath-shrubs area during a normal precipitation year, while both (interplant area and beneath-shrubs area) are similar in a dry year.

\section{Materials and methods}

\subsection{Study area}

This field experiment was conducted at the margin of the Fukang National Field Scientific Observation and Research Station for Desert Ecosystems, Chinese Academy of Sciences, on the 
southern edge of the Gurbantunggut Desert in the hinterland of the Eurasian continent $\left(44^{\circ} 17^{\prime} \mathrm{N}\right.$, $87^{\circ} 56^{\prime} \mathrm{E} ; 475 \mathrm{~m}$ a.s.1.). This region has a continental arid temperate climate, with a hot, dry summer and a cold winter. The annual mean temperature is $6.6^{\circ} \mathrm{C}$, while the mean annual precipitation is $160 \mathrm{~mm}$, of which $70 \%-80 \%$ occurs during the plant growing season from April to September. The multi-year winter average of snow thickness is $20 \mathrm{~cm}$. The soil here is classified as chestnut soil (Kastanozem), and is well drained with a low-moisture holding capacity. There is ca. 30\% vegetation cover, with the dominant plant species being Haloxylon ammodendron, $H$. persicum, and Tamarix ramosissima. The herbaceous layer is primarily composed of Alyssum linifolium, Astragalus arpilobus, Ceratocarpus arenarius, Descurainia sophia, Erodium oxyrrhynchum, Euphorbia turczaninowii, Hyalea pulchella, Lactuca undulate, Orostachys spinosus, Schismus arabicus, Trigonella arcuate, and Agriophyllum squarrosum. Similar to other desert ecosystems, the precipitation regime dramatically influences primary productivity in this desert, being strongly associated with inter-annual and intra-annual precipitation patterns (Schimel et al., 1990; Ojima et al., 1998).

\subsection{Experimental design and soil sampling}

We used a completely randomized block design with three treatments: natural precipitation (C), an extra $15 \%$ (P15), and an extra 30\% (P30) of precipitation added, with each treatment replicated six times. A total of 18 plots were arranged in a $4 \times 6$ matrix; each plot was $10 \mathrm{~m} \times 10 \mathrm{~m}$, with a 10 -m-wide buffer zone between adjacent plots. For the P15 and P30 treatments, precipitation was increased by $15 \%$ and $30 \%$ because these are predicted for northern China over the next 30 years from 2001 onward (Liu et al., 2010). Precipitation was collected in rainfall collection pans. These pans were constructed from galvanized iron sheets, each with a "catch" area of $1.5 \mathrm{~m} \times 1.0 \mathrm{~m}$. A total of 9 and 18 pans were installed in each $100-\mathrm{m}^{2}$ plot of the P15 and P30 treatments, amounting to ca. $15 \%$ and ca. $30 \%$ of the plot area, respectively. The pan was erected at an angle of 2 degrees, and the intercepted rainfall was collected in a bucket buried in the soil. Immediately after a precipitation event, the collected rain was evenly sprayed onto the plots. Further, given the importance of snow for the herbaceous community dynamics at our study site (Fan et al., 2012), snow that had fallen into the pan was also evenly added to the corresponding plot in early spring. The experimental design and instrument arrangements were applied in August 2010. In addition, in late March 2011, two square aluminum frames (each $0.5 \mathrm{~m} \times 0.5 \mathrm{~m}$ ) were put into the soil at a 3 -cm depth in each plot: one in the interplant matrix, and the other beneath the shrubs of $H$. ammodendron.

\subsection{Meteorological data, soil moisture, and temperature measurements}

Precipitation and air temperature were monitored hourly by an automatic meteorological station (Campbell Science Equipment, Logan, USA). Soil moisture at 0-10 cm depth was measured using time domain reflectometry (Diviner-2000, Sentek Pty Ltd., Balmain, Australia), while the soil temperature at $0-5 \mathrm{~cm}$ depth was measured using a thermocouple device (Microlab Lite, Fourier Technologies Ltd., Rosh HaAyin, Israel). Two probes, one for the time domain reflectometry and the other for the thermocouple, were installed in each plot, with one in the interplant space and the other beneath the shrubs of $H$. ammodendron. Soil moisture and temperature measurements were conducted on the same day as $\mathrm{CO}_{2}$ and $\mathrm{H}_{2} \mathrm{O}$ flux measurements.

\subsection{Carbon and water exchange measurement, and ecosystem WUE calculation}

Ecosystem $\mathrm{CO}_{2}$ and $\mathrm{H}_{2} \mathrm{O}$ fluxes were measured with a transparent chamber $(0.5 \mathrm{~m} \times 0.5 \mathrm{~m} \times 0.5 \mathrm{~m})$ attached to an infrared gas analyzer (IRGA; LI-840, LiCor, Lincoln, USA). This method has been widely used to measure ecosystem $\mathrm{CO}_{2}$ and $\mathrm{H}_{2} \mathrm{O}$ exchanges in previous field studies (e.g., Risch and Frank, 2007; Xia et al., 2009; Niu et al., 2011). The chamber walls were constructed by clear polyethylene sheeting, which allows $90 \%$ of photosynthetically active radiation to pass through it. Two electric cooling fans were installed to circulate the air in the chamber while the measurements were taken. $\mathrm{CO}_{2}$ and $\mathrm{H}_{2} \mathrm{O}$ fluxes were measured at 09:30-11:30, at 2-week 
intervals, during the plant growing seasons of 2011 and 2012 (i.e., from the start of April to the end of September). The chamber was sealed to the frame surface, and the two small electric fans ran continuously to promote air mixing within the chamber during and between measurements. Twelve consecutive recordings of $\mathrm{CO}_{2}$ and $\mathrm{H}_{2} \mathrm{O}$ were taken, at an interval of $10 \mathrm{~s}$ during a 120 -s period, after steady-state conditions were attained within the chamber. The observed increases in air temperatures were usually $<0.5^{\circ} \mathrm{C}$ within the chamber during the period of measurement. The $\mathrm{CO}_{2}$ and $\mathrm{H}_{2} \mathrm{O}$ concentrations were allowed to build up or decrease over time; the $\mathrm{CO}_{2}$ exchange and $\mathrm{H}_{2} \mathrm{O}$ efflux were determined from the time-course of the concentration to calculate net ecosystem exchange (NEE) and evapotranspiration (ET). Following the measurement of NEE, the chamber was vented and replaced on each frame and covered with an opaque cloth. Then, the $\mathrm{CO}_{2}$ exchange measurements were repeated. Because the second set of measurements eliminated light transmission (and hence photosynthesis was inhibited), these values obtained represented ecosystem respiration (ER), which is composed of plant dark respiration and soil respiration. The difference between the NEE and ER values was considered to represent the gross ecosystem exchange (GEE) for the vegetation within the chamber. NEE, ER, and ET were calculated following the formula below, described in the LI-840 manual:

$$
F_{\mathrm{c}}=\frac{10 V P_{0}\left(1-W_{0}\right)}{R S\left(T_{0}+273.15\right)} \frac{\partial C}{\partial t},
$$

where $F_{\mathrm{c}}$ is the $\mathrm{CO}_{2}\left(\mu \mathrm{mol} /\left(\mathrm{m}^{2} \cdot \mathrm{s}\right)\right)$ or $\mathrm{H}_{2} \mathrm{O}\left(\mathrm{mmol} /\left(\mathrm{m}^{2} \cdot \mathrm{s}\right)\right)$ exchange rate; $V$, the volume of the assimilation chamber $\left(75,000 \mathrm{~cm}^{3}\right) ; P_{0}$, the initial pressure $(\mathrm{kPa}) ; W_{0}$, the initial water vapor mole fraction $(\mu \mathrm{mol} / \mathrm{mol}) ; R$, the universal gas constant $(8.312 \mathrm{~kJ} /(\mathrm{mol} \cdot \mathrm{K})) ; S$, the soil surface area $\left(2500 \mathrm{~cm}^{2}\right) ; T_{0}$, the initial air temperature $\left({ }^{\circ} \mathrm{C}\right)$; and $\frac{\partial C}{\partial t}$, the slope of least squares linear regression of $\mathrm{CO}_{2}$ or $\mathrm{H}_{2} \mathrm{O}$ concentration as a function of time.

By convention, the negative $\mathrm{CO}_{2}$ exchange values refer to $\mathrm{CO}_{2}$ release, whereas the positive values represent $\mathrm{CO}_{2}$ uptake at the sampling site. Ecosystem WUE was calculated as GEE/ET (i.e., $\mathrm{WUE}_{\mathrm{GEE}}$ ) and NEE/ET (i.e., WUE $\mathrm{NEE}$ ) in our study.

\subsection{Photosynthesis measurements}

Leaf photosynthesis and transpiration rate measurements were only conducted for three dominant species, including the two spring ephemeral species (E. oxyrrhynchum and A. linifolium) and one spring-summer annual (C. arenarius). Growth peaks occurred in the middle of May for the spring ephemeral and in mid-August for the spring-summer annual, so our measurements were taken between 10:30 and 11:30 on 15 May, 2011 and 11 May, 2012 for spring ephemerals, and likewise on 20 August, 2011 and 2012 for the spring-summer annuals. Leaf photosynthesis $\left(\mathrm{P}_{\mathrm{n}}\right)$ and transpiration rate $\left(T_{L}\right)$ were measured with a $6-\mathrm{cm}^{2}$ clamp-on leaf cuvette attached to an open gas-exchange system (Li-6400; Li-Cor Inc., Lincoln, USA). Because the leaves of the three herbs were very small, typically $<1 \mathrm{~cm}^{2}$ in area for a single leaf, usually 3-5 leaves were placed into the leaf cuvette. In arranging the leaves, they were not overlapped, so as to correctly measure $\mathrm{P}_{\mathrm{n}}$ and $\mathrm{T}_{\mathrm{L}}$. During these measurements, the leaves were illuminated at $900 \mu \mathrm{mol} /\left(\mathrm{m}^{2} \cdot \mathrm{s}\right)$, using a LED light system. Immediately after taking the measurements, the leaves were cut with a pair of scissors and placed inside an envelope; samples were then stored at $4{ }^{\circ} \mathrm{C}$ in a refrigerator for subsequent leaf area measurements. We calculated the values of $\mathrm{P}_{\mathrm{n}}$ and $\mathrm{T}_{\mathrm{L}}$ based on the estimated leaf area by taking photos. Leaf WUE was calculated as $W U E_{L}=P_{n} / T_{L}$ (Jones, 2014).

\subsection{Vegetation biomass and WUE calculation}

Plant biomass was estimated using allometric equations that were obtained by the destructive sampling of $\geq 50$ individuals per species in 2010. The allometric equations for E. oxyrrhynchum, $A$. linifolium, $S$. arabicus, $S$. foliosa, and $C$. arenarius were $T A G B=0.0733 \mathrm{e}^{0.1327 H}$, $T A G B=0.0082 \mathrm{e}^{0.1175 H}, \quad T A G B=0.0177 \mathrm{e}^{0.1811 H}, T A G B=0.0359 \mathrm{e}^{0.1779 H}$ and $T A G B=0.115 \mathrm{e}^{0.2637 H}$, respectively, where TAGB and $\mathrm{H}$ express the total plant aboveground biomass $(\mathrm{g})$ and plant height (cm), respectively. All five $R^{2}$ values for the allometric equations were $>0.87$. In 2011 , five $1 \mathrm{~m} \times 1 \mathrm{~m}$ 
subplots were set up in each plot: two situated beneath shrubs, and three located in the interplant matrix space. Herbaceous plant height and individual counts of the five species were measured at growth peak in 2011 and 2012, respectively. According to one recent study, the biomass of the same five species amounts to more than $85 \%$ of the total community biomass at the study site (Huang and Li, 2015).

\subsection{Statistical analysis}

A repeated-measure ANOVA was used to test the effects of year (Y), water addition (W), microsite (S), and their possible interactions on six response variables: soil moisture, soil temperature, GEE, NEE, ET, and ecosystem WUE. If there was a significant inter-annual variability (i.e., a year effect, $P<0.05$ ), then separate two-way ANOVAs were used to further examine the main and interactive effects of water addition and site on the variables in 2011 and 2012. For $P_{n}, T_{L}$, and leaf WUE, a repeated-measure ANOVA was used to test the effects of $Y, W$, $\mathrm{S}$, and their possible interactions. For both of the two statistics, we initially included block as a random factor, it was then removed because it was insignificant in all cases. Pearson correlation analysis was used to test the linear associations of $\mathrm{WUE}_{\mathrm{GEE}}$, WUE $\mathrm{NEE}_{\mathrm{NE}}$, GEE, NEE, ET, and plant biomass with annual precipitation, those of GEE and NEE with ET, and those of $\mathrm{P}_{\mathrm{n}}, \mathrm{T}_{\mathrm{L}}$, and WUE $_{\mathrm{L}}$ with the soil moisture of the three plant species. All the statistical analyses reported here were conducted with SPSS software (SPSS for Windows, v13.0, Chicago, USA).

\section{Results}

\subsection{Microclimate}

Total annual precipitation differed between 2011 and 2012, being 167.4 and $102.0 \mathrm{~mm}$, respectively. Precipitation in 2011 was rather close to the long-term average annual precipitation, while precipitation in 2012 is lower than the average annual precipitation. Thus, we can consider the year of 2012 as a dry year. Meanwhile, precipitation in the two years showed strong seasonal variations, with $74.4 \%$ and $48.8 \%$ of the annual precipitation falling during the plant growing season in 2011 and 2012, respectively. The average soil volumetric water content (SVWC) in the control treatment was 3.44\% in 2011 and 3.63\% in 2012 (Figs. 1a-d). The P15 treatment did not significantly improve SVWC, but the P30 treatment markedly increased SVWC by an average of $1.9 \%$ in 2011 and $2.9 \%$ in 2012 . Soil temperature $\left(\mathrm{T}_{\mathrm{s}}\right)$ differed significantly between the two years (Figs. 1e-h; Table 1; $P<0.05$ ), but increasing precipitation exerted no discernible influences on $\mathrm{T}_{\mathrm{s}}$ (Figs. 1e-h; Table 1).

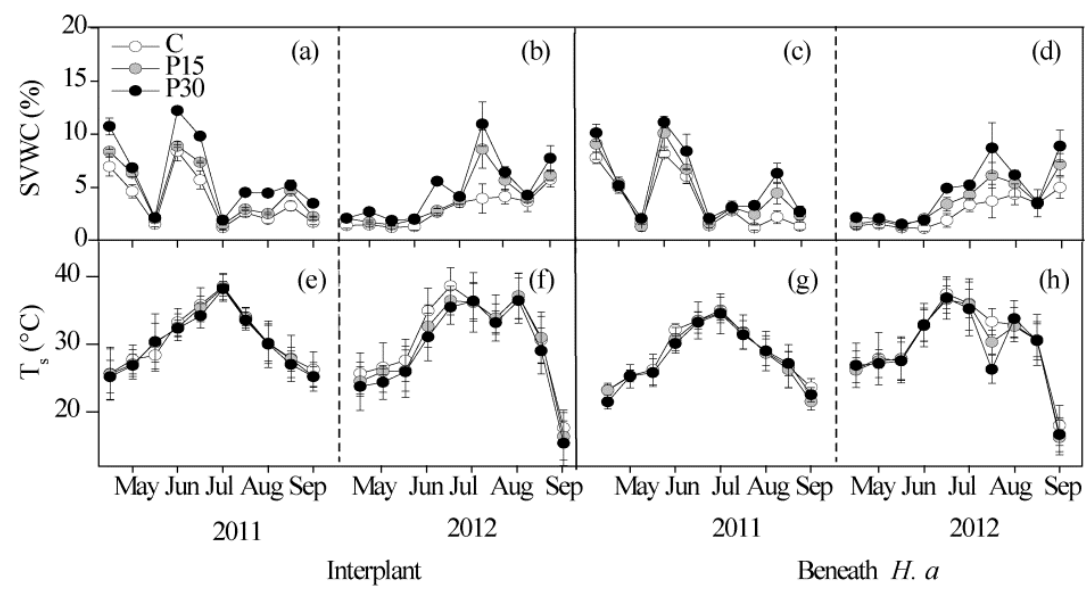

Fig. 1 Seasonal patterns of soil volumetric water content (SVWC) at 0-10 $\mathrm{cm}$ depth and soil temperature (T $\left.\mathrm{T}_{\mathrm{s}}\right)$ at 0-5 cm depth in the control (C), extra 15\% precipitation addition (P15), and extra 30\% precipitation addition (P30) in the interplant matrix and beneath the shrubs of Haloxylon ammodendron ("Beneath H. a") in 2011 and 2012. Bars represent standard errors. 
Table 1 ANOVA results for the effects of year (Y), precipitation (P), microsite $(\mathrm{S})$, and their interactions on soil volumetric water content (SVWC), soil temperature $\left(\mathrm{T}_{\mathrm{s}}\right)$, water-use efficiency (WUE $\mathrm{GEE}_{\mathrm{H}}$ and $\mathrm{WUE}_{\mathrm{NEE}}$ ), herbaceous aboveground biomass (Biomass), gross ecosystem carbon exchange (GEE), net ecosystem carbon exchange (NEE), and ecosystem evapotranspiration (ET)

\begin{tabular}{lcccccccc}
\hline Effect & SVWC & $\mathrm{T}_{\mathrm{s}}$ & WUE $_{\mathrm{GEE}}$ & WUE $_{\mathrm{NEE}}$ & Biomass & GEE & NEE & ET \\
\hline $\mathrm{Y}$ & $6.4^{* *}$ & $4.5^{*}$ & $37.0^{* * *}$ & $25.6^{* * *}$ & $70.4^{* * *}$ & $61.3^{* * *}$ & $75.3^{* * *}$ & $32.5^{* * *}$ \\
$\mathrm{Y} \times \mathrm{P}$ & 1.9 & 2.7 & 0.9 & $5.1^{*}$ & $6.4^{*}$ & 2.5 & $7.5^{* *}$ & 0.7 \\
$\mathrm{Y} \times \mathrm{S}$ & 1.1 & 2.1 & 0.0 & 0.6 & 2.1 & 0.0 & 0.6 & 0.1 \\
$\mathrm{Y} \times \mathrm{P} \times \mathrm{S}$ & 0.5 & 2.3 & 0.0 & 0.9 & 0.4 & 0.9 & 3.0 & 0.2 \\
$\mathrm{P}$ & $20.4^{* * *}$ & 2.4 & $9.7^{* * *}$ & $3.4^{*}$ & $20.5^{* * *}$ & $10.5^{* * *}$ & $3.9^{*}$ & $8.7^{* * *}$ \\
$\mathrm{~S}$ & 0.5 & 1.7 & 0.6 & 3.0 & 1.2 & $4.2^{*}$ & 2.3 & 2.1 \\
$\mathrm{P} \times \mathrm{S}$ & 0.7 & 0.4 & 0.9 & 1.8 & 2.4 & $4.8^{*}$ & $4.1^{*}$ & $3.9^{*}$ \\
\hline Note: ${ }^{* * * * *},{ }^{*}$ denote significance at $P<0.001, P<0.01$, and $P<0.05$ levels, respectively. & & &
\end{tabular}

\subsection{Leaf-level WUE in response to increasing precipitation}

Increasing precipitation significantly increased both $\mathrm{P}_{\mathrm{n}}$ and $\mathrm{T}_{\mathrm{L}}$, notably so for E. oxyrrhynchum (E. $o$ ) and A. linifolium (A. l) in 2011 and C. arenarius (C. a) in 2012 (Figs. 2a-d). Increasing precipitation slightly decreased leaf WUE of all three species, but this was not significant (Figs. 2e and f).

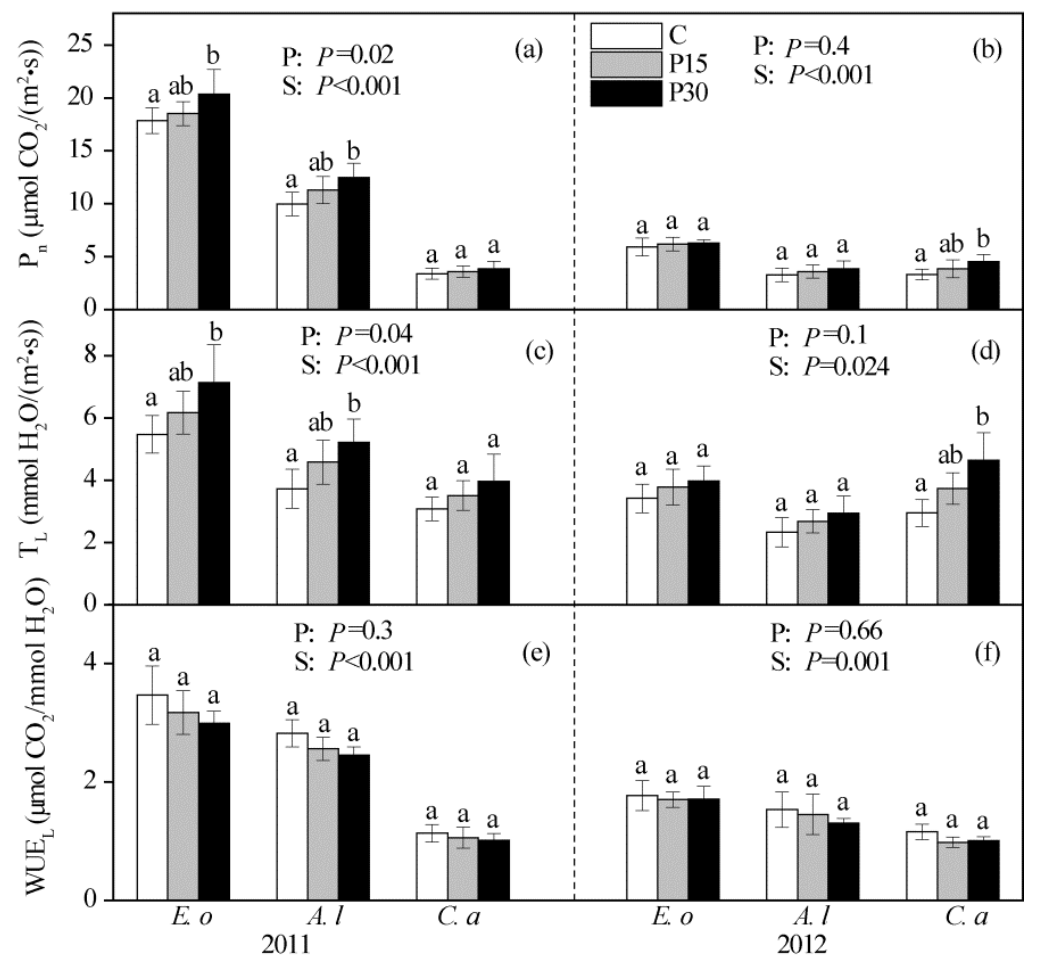

Fig. 2 Maximum leaf photosynthesis $\left(\mathrm{P}_{\mathrm{n}} ; \mathrm{a}, \mathrm{b}\right)$, leaf transpiration $\left(\mathrm{T}_{\mathrm{L}} ; \mathrm{c}, \mathrm{d}\right)$ and leaf water-use efficiency (WUE ; e, f) of two spring ephemerals, E. oxyrrhynchum (E.o) and A. linifolium (A. l), and one spring-summer annual, $C$. arenarius $(C$. a), in response to increased precipitation in 2011 and 2012 . Measurements were taken on 20 May for the spring ephemerals and on 15 August for the spring-summer annual. Bars represent standard errors. Different lowercase letters indicate a significant difference at $P<0.05$ level among precipitation treatments for a specific species. C, control; P15, extra 15\% precipitation addition; P30, extra 30\% precipitation addition. $\mathrm{P}$, precipitation; S, species.

\subsection{Ecosystem-level WUE in response to increasing precipitation}

$\mathrm{WUE}_{\mathrm{GEE}}$ and $\mathrm{WUE}_{\mathrm{NEE}}$ showed strong seasonal variations, ranging from 0 to $1.97 \mu \mathrm{mol} \mathrm{CO} \mathrm{CO}_{2} / \mathrm{mmol} \mathrm{H}_{2} \mathrm{O}$ 
for $\mathrm{WUE}_{\mathrm{GEE}}$ and from -2.37 to $0.31 \mu \mathrm{mol} \mathrm{CO} \mathrm{CO}_{2} / \mathrm{mmol} \mathrm{H}_{2} \mathrm{O}$ for $\mathrm{WUE}_{\mathrm{NEE}}$, respectively (Fig. 3). On average, P15 promoted $\mathrm{WUE}_{\mathrm{GEE}}$ by $13.1 \%$, and P30 promoted $\mathrm{WUE}_{\mathrm{GEE}}$ by $34.1 \%$ (Fig. 4). Increasing precipitation effects on $\mathrm{WUE}_{\mathrm{NEE}}$ was dependent on experimental year (Table 1). However, WUE $\mathrm{NEE}_{\mathrm{N}}$ only significantly increased with increasing precipitation in 2011, on average by $18.9 \%$ and $33.6 \%$ respectively under the P15 and P30 treatments, while no significant impacts were found in 2012 (Table 1). $\mathrm{WUE}_{\mathrm{GEE}}$ and $\mathrm{WUE}_{\mathrm{NEE}}$ were similar between the microsites of interplant matrix and beneath $H$. ammodendron shrubs (Table 1).

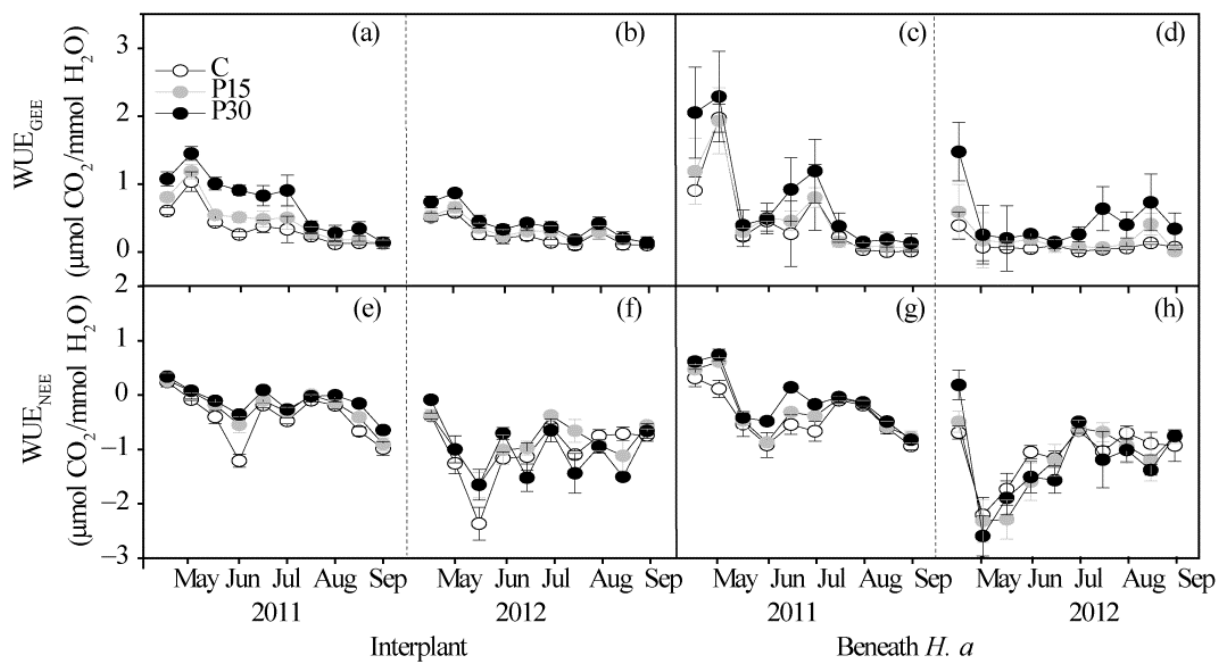

Fig. 3 Ecosystem water-use efficiency (WUE GEE $_{\text {(GEE/ET, a-d) and WUE }}$ (GEE (NEE/ET, e-h)) in response to increasing precipitation in the interplant matrix and beneath the shrubs of Haloxylon ammodendron ("Beneath $H$. a") in 2011 and 2012. Bars represent standard errors. C, control; P15, extra 15\% precipitation addition; P30, extra $30 \%$ precipitation addition.
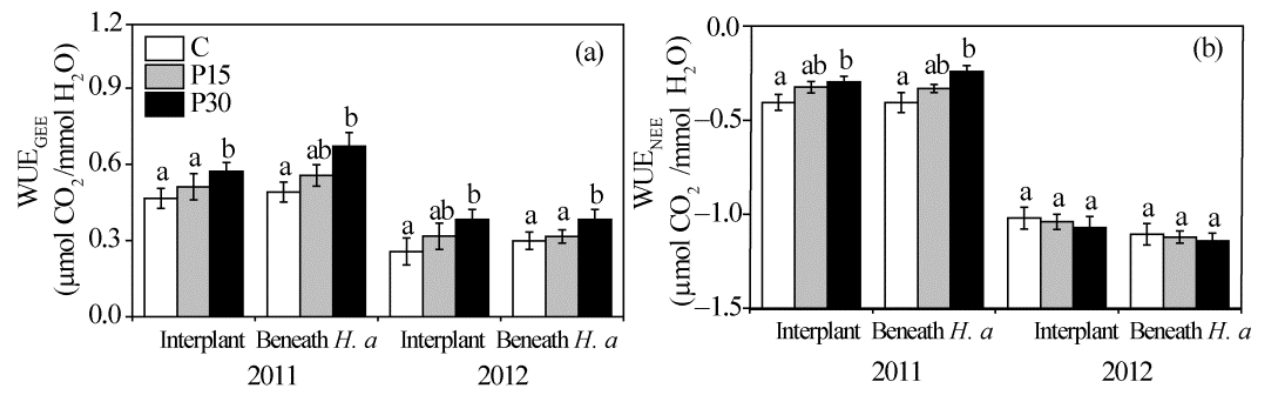

Fig. 4 Effects of increasing precipitation on the ecosystem water-use efficiency (WUE $\mathrm{GEE}_{\mathrm{GE}}$ (a) and $\mathrm{WUE}_{\mathrm{NEE}}(\mathrm{b})$ ) in the interplant matrix and beneath the shrubs of Haloxylon ammodendron ("Beneath H. a") in 2011 and 2012. Bars represent standard errors. Different lowercase letters indicate significant differences at $P<0.05$ level among the precipitation treatments within a species. C, control; P15, extra 15\% precipitation addition; P30, extra $30 \%$ precipitation addition.

\subsection{Responses of plant community composition to increasing precipitation and its correlation with WUE}

Increasing precipitation slightly increased the species richness of the plant community, but not in a statistically significant way (Table 2). Nevertheless, the densities of the dominant species $(E$. oxyrrhynchum, Alyssum linifolium, S. arabicus, Ceratocarpus arenarius and Salsola subcrassa) were all significantly higher under increasing precipitation than under the control in 2011; by contrast, no such difference was observed among the precipitation treatments in 2012 (Table 2).

Based on the community composition, we divided the plant-growing season into an ephemeral 
dominant phase and a summer-annual dominant phase. Regardless of the precipitation treatment, the proportion of plant biomass contributed by ephemerals and summer-annuals did not change, as the ephemerals consistently contributed more than $70 \%$ of the total community biomass during the ephemeral dominant phase, whereas the summer-annuals only contributed to community biomass after the ephemerals had died (Fig. 5). Both the P15 and P30 treatments significantly increased herbaceous plant biomass in the interplant matrix and beneath shrubs during the ephemeral dominant phase (Fig. 5), whereas only the P30 treatment significantly increased herbaceous biomass beneath shrubs after the death of the ephemerals (Fig. 5). Increasing precipitation significantly increased vegetation coverage by increasing ephemeral coverage during the ephemeral dominant phase in 2011 (Fig. 6), yet failed to exert a notable impact in 2012. Increasing precipitation apparently did not affect vegetation coverage during the summer-annual dominant phase in both years (Fig. 6).

Table 2 List of plant species within the subplots $(1 \mathrm{~m} \times 1 \mathrm{~m})$ in the interplant matrix microsite across two years (2011 and 2012) in the three precipitation treatments

\begin{tabular}{|c|c|c|c|c|c|c|c|}
\hline \multirow{2}{*}{ Species/Richness } & \multirow{2}{*}{ LH } & \multicolumn{3}{|c|}{$\begin{array}{c}\text { Herbaceous density in } 2011 \\
\left(\text { number } / \mathrm{m}^{2}\right)\end{array}$} & \multicolumn{3}{|c|}{$\begin{array}{c}\text { Herbaceous density in } 2012 \\
\left(\text { number } / \mathrm{m}^{2}\right)\end{array}$} \\
\hline & & $\mathrm{C}$ & P15 & P30 & $\mathrm{C}$ & $\mathrm{P} 15$ & P30 \\
\hline Erodium oxyrrhynchum & $\mathrm{E}$ & $53 \pm 8.0^{\mathrm{a}}$ & $67 \pm 8.0^{\mathrm{b}}$ & $64 \pm 3.0^{\mathrm{b}}$ & $12 \pm 1.1^{\mathrm{a}}$ & $13 \pm 1.0^{\mathrm{a}}$ & $18 \pm 1.3^{\mathrm{b}}$ \\
\hline Alyssum linifolium & $\mathrm{E}$ & $7 \pm 3^{\mathrm{a}}$ & $13 \pm 3^{b}$ & $12 \pm 4^{\mathrm{b}}$ & $15 \pm 3^{\mathrm{a}}$ & $20 \pm 3^{\mathrm{ab}}$ & $26 \pm 5^{b}$ \\
\hline Malcolmia africana & $\mathrm{E}$ & $6 \pm 1.0^{\mathrm{a}}$ & $6 \pm 1.0^{\mathrm{a}}$ & $13 \pm 5.0^{\mathrm{a}}$ & $1 \pm 0.6^{\mathrm{a}}$ & $2 \pm 0.5^{\mathrm{a}}$ & $3 \pm 1.0^{\mathrm{a}}$ \\
\hline Leptaleum filifolium & $\mathrm{E}$ & $18.0 \pm 12^{\mathrm{a}}$ & $12.0 \pm 3^{\mathrm{a}}$ & $19.0 \pm 6^{\mathrm{a}}$ & $0.2 \pm 0.2^{\mathrm{a}}$ & $0.5 \pm 0.2^{\mathrm{a}}$ & $0.4 \pm 0.2^{\mathrm{a}}$ \\
\hline Schismus arabicus & $\mathrm{E}$ & $30 \pm 17^{\mathrm{a}}$ & $45 \pm 23^{\mathrm{b}}$ & $42 \pm 20^{\mathrm{b}}$ & $8 \pm 4^{\mathrm{a}}$ & $27 \pm 10^{\mathrm{b}}$ & $48 \pm 17^{\mathrm{c}}$ \\
\hline Tragopogon ruber & $\mathrm{P}$ & $0.12 \pm 0^{\mathrm{a}}$ & $0.40 \pm 0.2^{\mathrm{a}}$ & $0.16 \pm 0.1^{\mathrm{a}}$ & $0.20 \pm 0.2^{\mathrm{a}}$ & $1.00 \pm 0^{\mathrm{a}}$ & $0.60 \pm 0.3^{\mathrm{a}}$ \\
\hline Nonea caspica & E & $2.70 \pm 1.6^{\mathrm{a}}$ & $0.12 \pm 0^{\mathrm{a}}$ & $0^{\mathrm{a}}$ & $5.00 \pm 0^{\mathrm{a}}$ & $3.00 \pm 1^{\mathrm{a}}$ & $3.50 \pm 1^{\mathrm{a}}$ \\
\hline Alyssum desertorum & E & $1.30 \pm 1^{\mathrm{a}}$ & $0^{\mathrm{a}}$ & $0.04 \pm 0^{\mathrm{a}}$ & $1.30 \pm 1.0^{\mathrm{a}}$ & $0^{\mathrm{a}}$ & $0.70 \pm 0.2^{\mathrm{a}}$ \\
\hline Amberboa turanica & E & $1.90 \pm 0.6^{\mathrm{a}}$ & $3.30 \pm 0.8^{\mathrm{a}}$ & $0.04 \pm 0^{\mathrm{a}}$ & $1.80 \pm 0.8^{\mathrm{a}}$ & $4.50 \pm 1.5^{\mathrm{b}}$ & $4.20 \pm 1.0^{\mathrm{b}}$ \\
\hline Arnebia guttata & $\mathrm{E}$ & $0^{\mathrm{a}}$ & $0^{\mathrm{a}}$ & $0.04 \pm 0^{\mathrm{a}}$ & $0^{\mathrm{a}}$ & $0^{\mathrm{a}}$ & $0^{\mathrm{a}}$ \\
\hline Nepeta micrantha & $\mathrm{E}$ & $0.30 \pm 0.1^{\mathrm{a}}$ & $0^{\mathrm{a}}$ & $0.04 \pm 0^{\mathrm{a}}$ & $0^{\mathrm{a}}$ & $0.80 \pm 0.2^{\mathrm{a}}$ & $0^{\mathrm{a}}$ \\
\hline Ceratocarpus arenarius & A & $8 \pm 7.0^{\mathrm{a}}$ & $12 \pm 5.9^{\mathrm{ab}}$ & $12 \pm 4.0^{\mathrm{b}}$ & $16 \pm 1.0^{\mathrm{a}}$ & $21 \pm 3.0^{\mathrm{b}}$ & $55 \pm 8.0^{\mathrm{c}}$ \\
\hline Salsola subcrassa & A & $146 \pm 95^{\mathrm{a}}$ & $177 \pm 38^{\mathrm{b}}$ & $173 \pm 48^{\mathrm{ab}}$ & $1.8 \pm 0.4^{\mathrm{a}}$ & $0^{\mathrm{a}}$ & $0.6 \pm 0.2^{\mathrm{a}}$ \\
\hline Tetracme recurvata & E & $0^{\mathrm{a}}$ & $0^{\mathrm{a}}$ & $0^{\mathrm{a}}$ & $0.4 \pm 0.2^{\mathrm{a}}$ & $0.9 \pm 0.2^{\mathrm{a}}$ & $0.8 \pm 0.2^{\mathrm{a}}$ \\
\hline Haloxylon ammodendron & $P$ & $2.6 \pm 1.9^{\mathrm{a}}$ & $4.0 \pm 1.3^{\mathrm{a}}$ & $1.6 \pm 0.6^{\mathrm{a}}$ & $0.8 \pm 0.5^{\mathrm{a}}$ & $0.8 \pm 0.2^{\mathrm{a}}$ & $0.8 \pm 0.2^{\mathrm{a}}$ \\
\hline Limonium bicolor & $\mathrm{P}$ & $0.08 \pm 0^{\mathrm{a}}$ & $0.16 \pm 0^{\mathrm{a}}$ & $0.04 \pm 0^{\mathrm{a}}$ & $0.80 \pm 0.6^{\mathrm{a}}$ & $0.40 \pm 0^{\mathrm{a}}$ & $0.50 \pm 0^{\mathrm{a}}$ \\
\hline Salsola passerina & $\mathrm{S}$ & $8.4 \pm 6.0^{\mathrm{a}}$ & $5.9 \pm 4.9^{\mathrm{a}}$ & $4.2 \pm 2.5^{\mathrm{a}}$ & $12.0 \pm 2.0^{\mathrm{a}}$ & $4.0 \pm 1.0^{\mathrm{b}}$ & $1.0 \pm 0.2^{\mathrm{b}}$ \\
\hline Descurainia sophia & $\mathrm{E}$ & $0.12 \pm 0^{\mathrm{a}}$ & $0^{\mathrm{a}}$ & $0.04 \pm 0^{\mathrm{a}}$ & $0^{\mathrm{a}}$ & $0^{\mathrm{a}}$ & $0^{\mathrm{a}}$ \\
\hline Chenopodium glaucum & A & $0.04 \pm 0^{\mathrm{a}}$ & $0^{\mathrm{a}}$ & $0^{\mathrm{a}}$ & $0^{\mathrm{a}}$ & $0^{\mathrm{a}}$ & $0^{\mathrm{a}}$ \\
\hline Euphorbia turczaninowii & A & $0^{\mathrm{a}}$ & $0^{\mathrm{a}}$ & $0^{\mathrm{a}}$ & $0.40 \pm 0.1^{\mathrm{a}}$ & $0^{\mathrm{a}}$ & $0.16 \pm 0^{\mathrm{a}}$ \\
\hline Salsola ruthenica & A & $0.12 \pm 0^{\mathrm{a}}$ & $0.04 \pm 0^{\mathrm{a}}$ & $0.04 \pm 0^{\mathrm{a}}$ & $0^{\mathrm{a}}$ & $0^{\mathrm{a}}$ & $0.50 \pm 0^{\mathrm{a}}$ \\
\hline Carex physodes & $\mathrm{P}$ & $0^{\mathrm{a}}$ & $1.2 \pm 1^{\mathrm{a}}$ & $0^{\mathrm{a}}$ & $0^{\mathrm{a}}$ & $0^{\mathrm{a}}$ & $0.8 \pm 0^{\mathrm{a}}$ \\
\hline Lactuca undulate & A & $0.12 \pm 0^{\mathrm{a}}$ & $0.08 \pm 0^{\mathrm{a}}$ & $0.08 \pm 0^{\mathrm{a}}$ & $0^{\mathrm{a}}$ & $0^{\mathrm{a}}$ & $0^{\mathrm{a}}$ \\
\hline Hyalea pulchella & A & $0.40 \pm 0.04^{\mathrm{a}}$ & $0.48 \pm 0.20^{\mathrm{a}}$ & $0.20 \pm 0.10^{\mathrm{a}}$ & $0.40 \pm 0^{\mathrm{a}}$ & $0.20 \pm 0^{\mathrm{a}}$ & $1.50 \pm 0.50^{\mathrm{a}}$ \\
\hline Seriphidiam santolinum & $\mathrm{P}$ & $0.40 \pm 0.2^{\mathrm{a}}$ & $0.12 \pm 0^{\mathrm{a}}$ & $0.20 \pm 0.1^{\mathrm{a}}$ & $0^{\mathrm{a}}$ & $0.50 \pm 0^{\mathrm{a}}$ & $0.20 \pm 0^{\mathrm{a}}$ \\
\hline Koelpina linearis & $\mathrm{P}$ & $0.04 \pm 0^{\mathrm{a}}$ & $0^{\mathrm{a}}$ & $0^{\mathrm{a}}$ & $0^{\mathrm{a}}$ & $0.80 \pm 0^{\mathrm{a}}$ & $0^{\mathrm{a}}$ \\
\hline Richness & & $12.0 \pm 0.3^{\mathrm{a}}$ & $13.4 \pm 1.0^{\mathrm{a}}$ & $14.0 \pm 1.0^{\mathrm{a}}$ & $8.8 \pm 0.6^{\mathrm{a}}$ & $10.0 \pm 0.6 \mathrm{a}$ & $11.8 \pm 0.7^{\mathrm{a}}$ \\
\hline
\end{tabular}

Note: Different lowercase letters indicate significant difference between treatments within rows for each year at $P<0.05$ level. $\mathrm{LH}, \mathrm{A}, \mathrm{P}$, and E respectively indicate life history, annual, perennial, and ephemeral plants. 

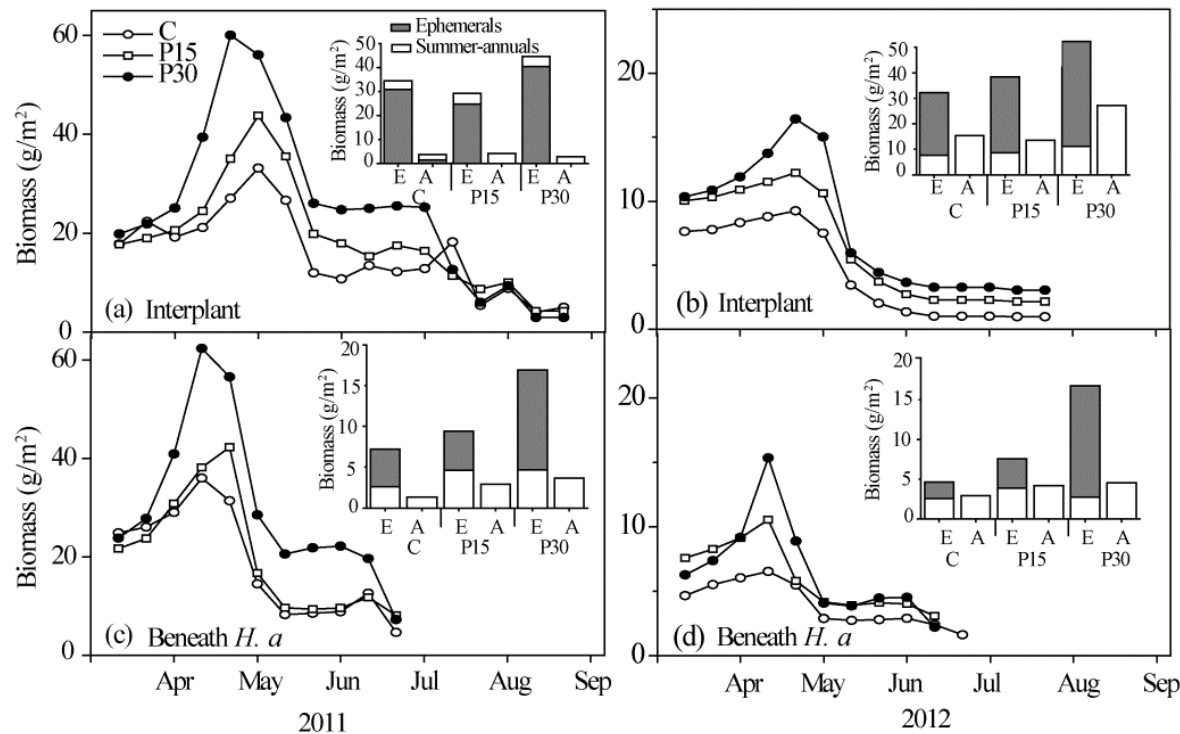

Fig. 5 Herbaceous community biomass in response to increasing precipitation in the interplant matrix $(a, b)$ and beneath the shrubs (c, d) of Haloxylon ammodendron in 2011 and 2012. The plant community's growing season could be divided into an ephemeral dominant phase (grey) and a summer-annual dominant phase (white). Insets in each panel show the proportion of biomass of ephemerals (E) and summer-annuals (A) in the two phases under the three precipitation treatments, measurements were conducted at the growth peak. C, control; P15, extra $15 \%$ precipitation addition; $\mathrm{P} 30$, extra $30 \%$ precipitation addition.
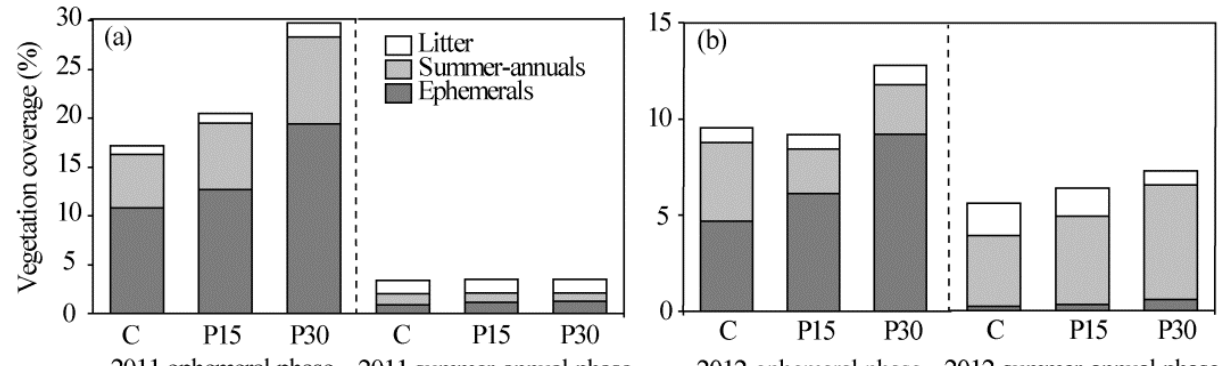

2011 ephemeral phase 2011 summer-annual phase

2012 ephemeral phase 2012 summer-annual phase

Fig. 6 Herbaceous vegetation coverage in response to increasing precipitation at the growth peak of the ephemerals and the summer-annuals in 2011 (a) and 2012 (b). C, control; P15, extra 15\% precipitation addition; P30, extra $30 \%$ precipitation addition.

\subsection{Factors affecting the ecosystem WUE}

WUE was positively correlated with GEE and ET (Figs. 7a and b) in 2011, whereas WUE was negatively correlated with ET in 2012 (Fig. 7b). No significant relationship was found between WUE and plant biomass (Fig. 7c). However, for the interplant matrix, WUE was positively correlated with vegetation coverage in 2011 but this relationship was negative and at near significance in 2012 (Fig. 7d).

\section{Discussion}

\subsection{Ecosystem WUE in response to increasing precipitation}

The $W_{U E} E_{N E E}$ varied from -2.71 to $-1.00 \mathrm{~g} \mathrm{C} / \mathrm{kg} \mathrm{H}_{2} \mathrm{O}$ in our study. Using the eddy covariance technique, we measured WUE $\mathrm{NEE}_{\mathrm{N}}$ and the measured values ranged from -2.30 to $0.90 \mathrm{~g} \mathrm{C} / \mathrm{kg} \mathrm{H}_{2} \mathrm{O}$ in a 2-year study with annual precipitations of 147 and $197 \mathrm{~mm}$ in a desert shrub ecosystem (Hastings et al., 2005). Using the eddy covariance technique at our study site, Liu et al. (2012) measured $\mathrm{WUE}_{\mathrm{NEE}}$ and reported that the values were 0.03 and $0.15 \mathrm{~g} \mathrm{C} / \mathrm{kg} \mathrm{H}_{2} \mathrm{O}$ under annual 
precipitations of 127 and $231 \mathrm{~mm}$, respectively. In our study, the negative WUE $E_{\mathrm{NEE}}$ was resulted from the negative values of NEE, suggesting that precipitation-induced ecosystem carbon release exceeds that of carbon uptake via herbaceous plant growth. The positive values for NEE in this desert measured from the eddy covariance method mainly occurred during the night, largely due to the downward carbon absorption by the alkaline soil (Ma et al., 2012). As our carbon exchange measurements were taken only in the daytime, the NEE can represent the carbon release occurring most of the time in the growing season.
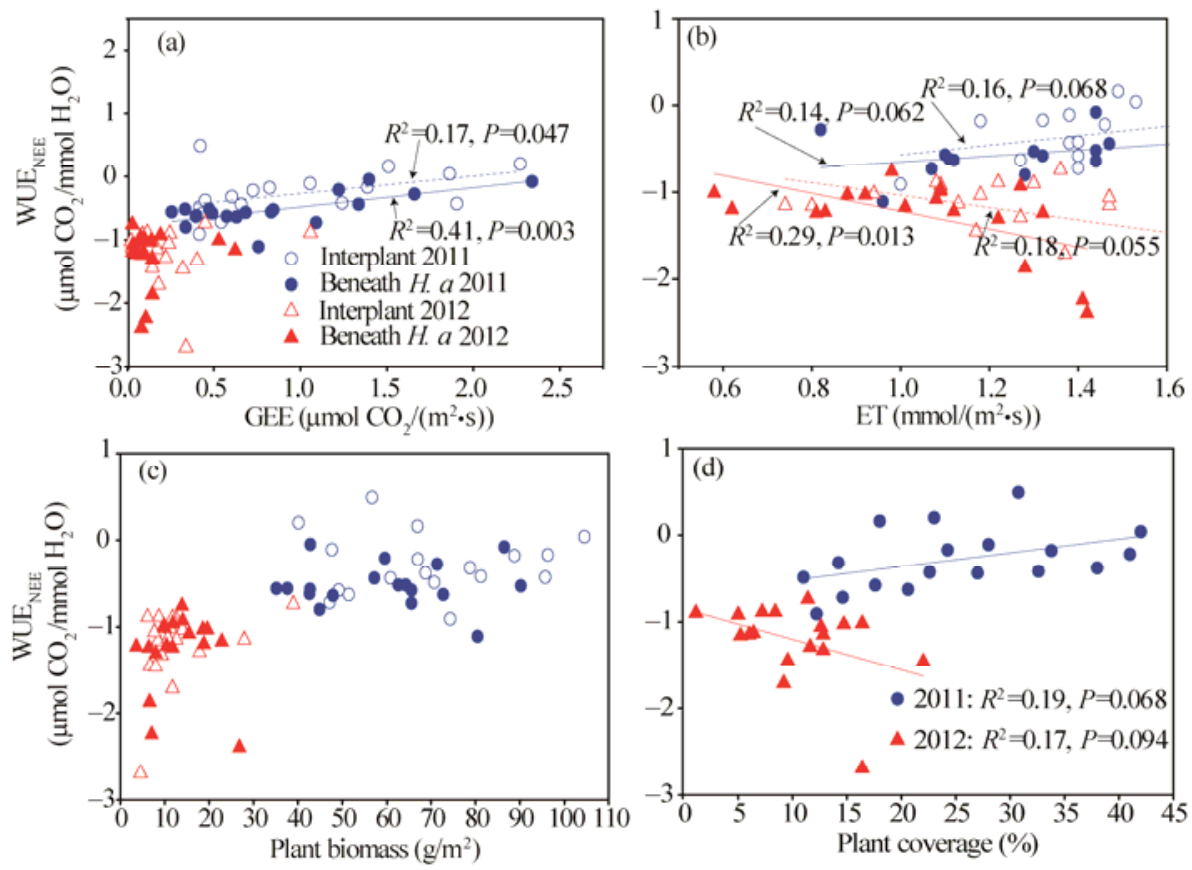

Fig. 7 Linear relationships between ecosystem water-use efficiency (WUE) and ecosystem carbon exchange (GEE, a), ecosystem evapotranspiration (ET, b), plant biomass (c), and vegetation coverage (d) in the interplant matrix and beneath the shrubs of Haloxylon ammodendron ("Beneath H. a") in 2011 and 2012

WUE $_{\mathrm{NEE}}$ responded differently to increasing precipitation in the two study years. In the normal precipitation year (2011), increasing precipitation significantly increased WUE $\mathrm{NEE}_{\mathrm{N}}$; however, increasing precipitation inhibited WUE $\mathrm{NEE}_{\mathrm{in}}$ in the dry year (2012). The results illustrate that the effects of increasing precipitation on ecosystem WUE depend on its stimulation of plant growth (Cohen, 1970; Golluscio and Oesterheld, 2007; Liu et al., 2012). In the normal precipitation year (2011), $67.9 \mathrm{~mm}$ of precipitation fell during the ephemeral growing season, representing $54.3 \%$ of the precipitation for the entire growing season. Correspondingly, increasing precipitation in 2011 met the water requirement of the spring ephemerals, leading to stark increases in NEE and decreases in ET. In the dry year (2012), when only $20.9 \mathrm{~mm}$ of precipitation fell during the ephemeral growing season, a large amount of precipitation occurred in the summer-annual growing phase; thus the increasing precipitation applied was able to meet the water requirement of the summer-annuals. The relative importance of the two functional herb groups can be seen in terms of their biomass and coverage: ephemerals contributed to more than $70 \%$ of the herbaceous biomass. Therefore, increasing precipitation exerted a stronger stimulation on NEE than on ET, leading to the increased WUE seen in 2011. However, increasing precipitation resulted in a decreased NEE and similar ET, leading to a decreased WUE in 2012.

Our study implies that changes in community composition can influence the response of WUE to increasing precipitation. Although WUE showed a positive correlation with precipitation amounts at the ecosystem level (Varnamkhasti et al., 1995; Ruppert et al., 2012), increasing precipitation may exert a different effect on different vegetation types (Huxman et al., 2004). In 
addition, the seasonal pattern of the precipitation regime should be considered when predicting precipitation effects on ecosystem WUE.

\subsection{Leaf WUE and ecosystem WUE respond differently to increasing precipitation}

Leaf WUE (the ratio of leaf $\mathrm{CO}_{2}$ assimilation rate to the transpiration rate) has been widely studied through direct measurement of instantaneous gas exchange rates at the leaf level, often with portable equipment and a carbon isotopic measurement used for longer time periods (Toft et al., 1989; Wang et al., 2005; Golluscio and Oesterheld, 2007; Wu et al., 2016). Leaf WUE is controlled principally by leaf stomatal dynamics. Although leaf WUE varies at daily and seasonal scales, the values measured at certain times (i.e., at mid-morning) are used to represent the whole-day WUE. To date, we have not reached consensus yet as for how leaf WUE responds to increasing water availability in arid and semi-arid regions (Cohen, 1970; Ehleringer and Cooper, 1988; Toft et al., 1989; Lin et al., 1996; Golluscio and Oesterheld, 2007). In our study, WUE slightly decreased with the increasing precipitation, regardless of plant species, which suggests a stronger stimulation of leaf transpiration than photosynthesis.

To be partial supportive to our first hypothesis, $W_{U E E}$ responded differently from $W_{\mathrm{NE}}$ to the increasing precipitation treatments in our study. WUE $\mathrm{NEE}_{\mathrm{N}}$ increased with increasing precipitation, while $\mathrm{WUE}_{\mathrm{L}}$ slightly decreased in 2011. Unfortunately, little is known about how leaf-scale variation in WUE influences landscape-scale variation in ecosystem WUE (Linderson et al., 2012). On one hand, due to a large spatial variation of leaf WUE within and among different vegetation canopies, it is difficult to reliably extrapolate leaf WUE to the whole-plant WUE and ecosystem WUE (Niu et al., 2011; Medlyn et al., 2017). On the other hand, ecosystem respiration and soil evaporation are two important factors controlling ecosystem WUE, but how they responded to increasing precipitation in our study remained unknown. The relationship between leaf WUE and ecosystem WUE was reportedly different from some studies to other studies and the difference was probably caused by different factors considered in different studies. In brief, the previous studies show that leaf WUE hardly explained the variation of ecosystem WUE (Niu et al., 2011; Medlyn et al., 2017). The response of ecosystem WUE to increasing precipitation is strongly dependent on the effects of increased water availability on the recipient herbaceous community, and water availability determines ecosystem NEE and ET in our study. The increased NEE in 2011 was clearly related to the strong increase in plant biomass. Community biomass under the extra 30\%-increasing precipitation (P30) was nearly 2.5 times that of the control, and this increased plant biomass contributed to the greater increase in GEE than in ER. Meanwhile, the increased vegetation cover under increasing precipitation also decreased the soil evaporation. Thus, the increased biomass and decreased soil evaporation together generated the positive response of ecosystem WUE to the increasing precipitation. In contrast, an increased GEE was insufficient to offset ER and to decrease soil evaporation under the increasing precipitation in 2012; thus, ecosystem WUE was not altered by increasing precipitation. Our results indicate the ecosystem WUE response to increasing precipitation is related not only to the precipitation amount but also to the precipitation seasonality and plant functional groups.

\subsection{Responses of ecosystem WUE to increasing precipitation under two contrasting microsites}

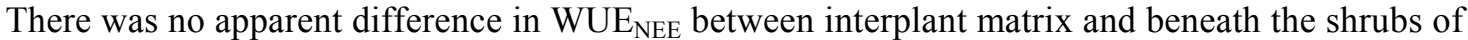
H. ammodendron in the normal precipitation (2011) and dry (2012) years. This result does not support our second hypothesis: ecosystem WUE is higher in the interplant soil microsite than that beneath shrubs in the normal precipitation year, and ecosystem WUE is similar in the dry year both in the interplant matrix and the beneath shrubs. No differences in ecosystem WUE $_{\mathrm{NEE}}$ between two habitats are attributable to the similar plant biomass and vegetation cover. Previous studies have shown that an alteration of the dominant species can cause marked changes in ecosystem WUE, which is not only related to species-specific photosynthetic traits but also to the alteration in soil respiration and soil $\mathrm{H}_{2} \mathrm{O}$ fluxes induced by a changed canopy structure (Golluscio and Oesterheld, 2007; Niu et al., 2011; Eamus et al., 2013). Community composition in the interplant matrix microsite was different from that found beneath shrubs and was largely 
driven by rare and accompanying species, whereas the dominant species were the same or had similar functional traits both in the interplant matrix and the beneath shrubs. For example, in the ephemeral growing phase, E. oxyrrhynchum comprised most of the community biomass of the interplant microsite, while $S$. arabicus and $C$. glaucum were the major contributors to the vegetation beneath shrubs. However, in the summer-annual growing phase, Salsola subcrassa and $S$. passerine were the major contributors, respectively, to the community biomass of the interplant matrix and beneath shrubs. NEE and ET showed no discernible difference between the two microsites in the normal precipitation year (2011), leading to similar ecosystem WUEs. In the dry year (2012), NEE and ET showed synchronous increases for the interplant matrix, giving rise to similar ecosystem WUEs between the two microsites. The dominant species were always similar between the two habitats, thus community structure and coverage were also similar. By comparing the results of ecosystem WUE between typical microsites in a desert ecosystem, this study revealed that WUE was similar between the interplant matrix and beneath shrubs in this desert in China.

\section{Conclusions}

In this study, we found that leaf WUE and ecosystem WUE showed inconsistent responses to increasing precipitation. Leaf WUE consistently decreased as precipitation increased. By contrast, the responses of the ecosystem WUE to increasing precipitation are different in different precipitation regimes: increasing by $33.9 \%$ in the wet year (i.e., the normal precipitation years) and decreasing by $4.1 \%$ in the dry year when the precipitation was about $30 \%$ less than that in the wet year. Increasing precipitation increased plant biomass, but it did not shift the relative significance of ephemerals in this vegetation community, thus increasing ecosystem WUE in 2011. By contrast, increasing precipitation exerted no significant effects on ecosystem WUE in 2012 because plant biomass could not respond to it in a dry year. Our field study shows that the effects of increasing precipitation on ecosystem WUE depended heavily on the stimulating effects of the dominant species in the plant community. Hence, altering the community composition through changing precipitation regime could predictably shift ecosystem WUE in this desert ecosystem.

\section{Acknowledgements}

This work was supported by the Science Fund for Distinguished Young Scholars in the Xinjiang Uygur Autonomous Region (QN2015JQ007). We greatly appreciate all the staff at the Fukang National Field Scientific Observation and Research Station for Desert Ecosystems, Chinese Academy of Sciences, for their excellent help in setting up and maintaining the field experiment and facilities, and for assistance with the field measurements.

\section{References}

Austin A T, Yahdjian L, Stark J M, et al. 2004. Water pulses and biogeochemical cycles in arid and semiarid ecosystems. Oecologia, 141(2): 221-235.

Bell T W, Menzer O, Troyo-Diéquez E, et al. 2012. Carbon dioxide exchange over multiple temporal scales in an arid shrub ecosystem near La Paz, Baja California Sur, Mexico. Global Change Biology, 18(8): 2570-2582.

Cohen D. 1970. The expected efficiency of water utilization in plants under different competition and selection regimes. Israel Journal of Botany, 19(1): 50-54.

Eamus D, Cleverly J, Boulain N, et al. 2013. Carbon and water fluxes in an arid-zone Acacia savanna woodland: an analyses of seasonal patterns and responses to rainfall events. Agricultural and Forest Meteorology, 182-183: 225-238.

Ehleringer J R, Cooper T A. 1988. Correlations between carbon isotope ratio and microhabitat in desert plants. Oecologia, 76(4): $562-566$.

Fan L L, Ma J, Wu L F, et al. 2012. Response of the herbaceous layer to snow variability at the south margin of the Gurbantonggut Desert of China. Chinese Journal of Plant Ecology, 36(2): 126-135. (in Chinese)

Golluscio R A, Oesterheld M. 2007. Water use efficiency of twenty-five co-existing Patagonian species growing under different soil water availability. Oecologia, 154(1): 207-217. 
Hastings S J, Oechel W C, Muhlia-Melo A. 2005. Diurnal, seasonal and annual variation in the net ecosystem $\mathrm{CO}_{2}$ exchange of a desert shrub community (Sarcocaulescent) in Baja California, Mexico. Global Change Biology, 11(6): 927-939.

Huang G, Li Y, Padilla F M. 2015. Ephemeral plants mediate responses of ecosystem carbon exchange to increased precipitation in a temperate desert. Agricultural and Forest Meteorology, 201: 141-152.

Huang G, Li Y. 2015. Phenological transition dictates the seasonal dynamics of ecosystem carbon exchange in a desert steppe. Journal of Vegetation Science, 26(2): 337-347.

Huxman T E, Smith M D, Fay P A, et al. 2004. Convergence across biomes to a common rain-use efficiency. Nature, 429(6992): 651-654.

Jones H G. 2014. Plants and Microclimate: A Quantitative Approach to Environmental Plant Physiology (3 ${ }^{\text {rd }}$ ed.). Cambridge: Cambridge University Press, 407.

Lal R. 2004. Carbon sequestration in dryland ecosystems. Environmental Management, 33(4): 528-544.

Law B E, Falge E, Gu L. 2002. Environmental controls over carbon dioxide and water vapor exchange of terrestrial vegetation. Agricultural and Forest Meteorology, 113(1-4): 97-120.

Le Houerou H N. 1984. Rain use efficiency: a unifying concept in arid-land ecology. Journal of Arid Environments, 7(3): 213247.

Li X R. 2012. Eco-Hydrology of Biological Soil Crusts in Desert Regions of China. Beijing: Higher Education Press, 9-46. (in Chinese)

Lin G H, Phillips S L, Ehleringer J R. 1996. Monosoonal precipitation responses of shrubs in a cold desert community on the Colorado Plateau. Oecologia, 106(1): 8-17.

Linderson M L, Mikkelsen T N, Ibrom A, et al. 2012. Up-scaling of water use efficiency from leaf to canopy as based on leaf gas exchange relationships and the modeled in canopy light distribution. Agricultural and Forest Meteorology, 152: 201-211.

Liu R, Pan L P, Jenerette G D, et al. 2012. High efficiency in water use and carbon gain in a wet year for a desert halophyte community. Agricultural and Forest Meteorology, 162-163: 127-135.

Liu Y X, Li X, Zhang Q, et al. 2010. Simulation of regional temperature and precipitation in the past 50 years and the next 30 years over China. Quaternary International, 212(1): 57-63.

Ma J, Zheng X J, Li Y. 2012. The response of $\mathrm{CO}_{2}$ flux to rain pulses at a saline desert. Hydrological Processes, 26(26): 40294037.

Medlyn B E, De Kauwe M G, Lin Y S, et al. 2017. How do leaf and ecosystem measures of water-use efficiency compare? New Phytologist, doi: 10.1111/nph.14626.

Niu S L, Xing X R, Zhang Z, et al. 2011. Water-use efficiency in response to climate change: from leaf to ecosystem in a temperate steppe. Global Change Biology, 17(2): 1073-1082.

Ojima D S, Xiao X M, Chuluun T, et al. 1998. Asian grassland biogeochemistry: factors affecting past and future dynamics of Asian grasslands. In: Galloway J N, Melillo J M. Asian Change in the Context of Global Climate Change: Impact of Natural and Anthropogenic Changes in Asia on Global Biogeochemical Cycles. Cambridge: Cambridge University Press, $128-144$.

Potts D L, Huxman T E, Scott R L, et al. 2006. The sensitivity of ecosystem carbon exchange to seasonal precipitation and woody plant encroachment. Oecologia, 150(3): 453-463.

Risch A C, Frank D A. 2007. Effects of increased soil water availability on grassland ecosystem carbon dioxide fluxes. Biogeochemistry, 86(1): 91-103.

Robertson T R, Zak J C, Tissue D T. 2010. Precipitation magnitude and timing differentially affect species richness and plant density in the sotol grassland of the Chihuahuan Desert. Oecologia, 162(1): 185-197.

Ruppert J C, Holm A, Miehe S, et al. 2012. Meta-analysis of ANPP and rain-use efficiency confirms indicative value for degradation and supports non-linear response along precipitation gradients in drylands. Journal of Vegetation Science, 23(6): $1035-1050$.

Scanlon T M, Albertson J D. 2004. Canopy scale measurements of $\mathrm{CO}_{2}$ and water vapor exchange along a precipitation gradient in southern Africa. Global Change Biology, 10(3): 329-341.

Schimel D S, Parton W J, Kittel T G F, et al. 1990. Grassland biogeochemistry: links to atmospheric processes. Climatic Change, 17(1): 13-25.

Su Y G, Li X R, Cheng Y W, et al. 2007. Effects of biological soil crusts on emergence of desert vascular plants in North China. Plant Ecology, 191(1): 11-19.

Su Y G, Wu L, Zhou Z B, et al. 2013. Carbon flux in deserts depends on soil cover type: a case study in the Gurbantunggute desert, North China. Soil Biology and Biochemistry, 58: 332-340.

Thomey M L, Collins S L, Vargas R, et al. 2011. Effect of precipitation variability on net primary production and soil respiration in a Chihuahuan Desert grassland. Global Change Biology, 17(4): 1505-1515. 
Toft N L, Anderson J E, Nowak R S. 1989. Water use efficiency and carbon isotope composition of plants in a cold desert environment. Oecologia, 80(1): 11-18.

Varnamkhasti A S, Milchunas D G, Lauenroth W K, et al. 1995. Production and rain use efficiency in short-grass steppe: grazing history, defoliation and water resource. Journal of Vegetation Science, 6(6): 787-796.

Veron S V, Paruelo J M, Sala O E, et al. 2002. Environmental controls of primary production in agricultural systems of the Argentine Pampas. Ecosystems, 5(7): 625-635.

Wang R Z, Liu X Q, Xing Q, et al. 2005. Photosynthesis, transpiration, and water use efficiency of Leymus dasystachys on the Hunshandake Desert. Photosynthetica, 43(2): 289-291.

Webb W L, Lauenroth W K, Szarek S R, et al. 1983. Primary production and abiotic controls in forests, grasslands, and desert ecosystems in the United States. Ecology, 64(1): 134-151.

Wu Y, Zheng X J, Li Y. 2016. Photosynthetic response of desert plants to small rainfall events in the Junggar Basin, Northwest China. Photosynthetica, 54(1): 3-11.

Xia J Y, Niu S L, Wan S Q. 2009. Response of ecosystem carbon exchange to warming and nitrogen addition during two hydrologically contrasting growing seasons in a temperate steppe. Global Change Biology, 15(6): 1544-1556. 